Revista Portuguesa de História

t. XXXIV (2000)

\title{
Tipologias de regimes políticos. Para uma leitura neomoderna do Estado Novo e do Nuevo Estado
}

JOÃO PAULO AVELÃS NUNES

Universidade de Coimbra

\section{Objectivos e limitações}

Inicia-se este artigo afirmando a ausência de qualquer propósito, tanto de elaboração de uma síntese 'conclusiva' acerca do amplo, multifacetado e interdisciplinar debate científico-ideológico que envolve o estudo dos regimes políticos estruturados ao longo do século XX - com destaque para ambos os países ibéricos -, como, menos ainda, de descoberta de uma leitura 'definitiva' sobre aquelas mesmas temáticas. Visa-se, simplesmente, manifestar concordância com algumas das interpretações já aventadas, assim como introduzir tópicos ou exemplos complementares.

Versão ampliada e actualizada do texto da comunicação com o mesmo título apresentada no Encontro "Relações Portugal-Espanha: uma história paralela, um destino comum?" (Zamora, 7 e 8 de Julho de 2000), organização do CEPFAM/CEPESE da Universidade do Porto e da Fundação Rei Afonso Henriques. 
Tratando-se, embora, de uma polémica antiga, de âmbito predominantemente abstracto (epistemológico e teórico-metodológico), recusa-se a conclusão de que nos encontramos perante uma querela cada vez mais esvaziada de sentido porque sem ligação à realidade dos nossos dias; afastada da investigação de ponta, factualista ou baseada em modelos "micro" depois de confirmada a inoperatividade dos grandes sistemas explicativos; em contradição com as actuais necessidades do ensino e da divulgação cultural; relevante, quando muito, para um universo limitado de "especialistas" - estudiosos, professores, "fazedores de opinião", políticos.

Em favor da tese da pertinência científica e da actualidade cívica da reflexão sobre os conceitos de autoritarismo, fascismo e totalitarismo em geral, quanto à natureza do Estado Novo português e do Nuevo Estado espanhol em particular, é possível apresentar, nomeadamente, os seguintes argumentos:

a) devido ao colapso de grande parte dos "socialismos reais" e ao fim da "guerra fria", à possibilidade de acesso a nova documentação e ao desenvolvimento das ciências sociais em países onde haviam vigorado regimes ditatoriais, à continuação do confronto de ideias entre investigadores, jornalistas e outros intelectuais, têm surgido diferentes propostas de reconstituição e hipóteses de análise ${ }^{2}$;

b) uma vez superada a fase de mais aguda reacção subjectivista e

${ }^{2}$ Refiram-se temáticas como o Holocausto enquanto modalidade extrema de exercício da violência (do "terror de massas") por parte de aparelhos de Estado e de sociedades; o "ouro nazi" antes, durante e após a Segunda Guerra Mundial, neutralidade, direito internacional e relações entre países em situação de conflito militar e civilizacional generalizado; características dos vários regimes políticos e explicação das atitudes assumidas perante os mesmos (nos planos nacional e internacional); função central desempenhada pelas religiosidades e igrejas na configuração das realidades sociais globais.

Cfr., entre outros, S. Berstein, 1992; J. Catalan, 1995; S. Cerqueira, 1973; J. Cornwell. 2000; M.B. Cruz, 1982b; M.B. Cruz, 1998; B. Droz, 1988-1993; F. Furet, 1998; R. Garcia Pérez, 1994; E. Hobsbawm, 1996; E. Husson, 1997; Informe para la Comisión [...], 1998; A. Louçã, 2000; J.RA. Nunes, 1993a; J.P.A. Nunes, 1999b; A.F.K. Organsky. 
neo-empirista, quer à crise global do paradigma moderno, quer a algum excesso de teoricismo presente num segmento dos discursos historiográficos acerca da evolução da humanidade, voltou-se a reconhecer, mesmo entre os profissionais da história, o carácter imprescindível dos modelos de grande, média e pequena dimensão enquanto instrumentos de trabalho científico ${ }^{3}$;

c) a desagregação da generalidade das concretizações (estalinistas) do projecto socialista/comunista, a situação de crise global vivida pela quase totalidade dos Estados periféricos, os sintomas de disfunção que se têm acentuado no conjunto da economia-mundo capitalista e, mesmo, nos países semi-periféricos e centrais, resultaram, tanto na intensificação da luta pelo controlo dos mecanismos de reprodução da memória histórica e da identidade, como na importância crescente de um acesso alargado, por parte dos cidadãos - através dos sistemas de ensino/formação, dos mass media, da indústria cultural, etc. -, a um debate plural e frontal, objectivante e complexificante, não-anacrónico e não-maniqueísta sobre a história como um todo e, antes de mais, acerca da época contemporânea ${ }^{4}$.

1965; G.J. Pita, 1996/1997; M.I. Rezola, 1999; F. Rosas, 1990; H. Rousso, 1999; A.J. Telo, 2000.

Cfr., nomeadamente, J.M.F. Branco, 1996; E. Fernández Clemente, 1995; C. Forcadell Álvarez, 1995; P. Nora, 1989; A.S. Nunes, 1970; B.S. Santos, 1987; E.M. Wood, 1996.

"Ya sabemos, ya sabíamos, que el proceso histórico no está sujeto a pautas preestabelecidas por una filosofía emancipatoria de raiz ilustrada, que la historia no está tejida por un hilo [...], pero ese convencimiento no debe ser una escusa suficiente para olvidar a los agentes sociales que han sido portadores, contra otros agentes sociales, de valores ideológicos, políticos y éticos que rellenan el cuarto de la esperanza de nuestro presente desde consensos mayoritarios, al menos en aparencia [...]. Pues frente al fin de la historia de Fukuyama siempre será mejor encarar desde nuestro trabajo una historia sin fin que padecer el fin de la historia, y frente al relativismo axiológico de la posmodernidad seguirá siendo conveniente [...] construir "compromisos" cara a unas "realidades" no deconstruidas." (C. Forcadell Álvarez, 1995, p. 58)

Cfr., entre outros, G. Erler, 1988; E. Hobsbawm, 1996; E. Husson, 1997; G. Kantin, 1991; M. Loff, 1997; J.A. Nunes, 1990; J.P.A. Nunes, 1999a; H. Rousso, 1999. 


\section{Pós-modernidade e neo-modernidade}

Resultado e, ao mesmo tempo, vector de condicionamento da evolução próxima - nas últimas três décadas -, sobretudo dos países desenvolvidos, a chamada "revolução pós-moderna" tem influenciado, de forma decisiva, entre outras, a regionalidade ideológico-cultural. Tratou-se, inicialmente, de uma contestação, multiforme mas quase consensual, à excessiva confiança depositada na ciência e na tecnologia como vectores exclusivos e universais de análise e de resolução dos problemas derivados do controlo das relações humanas e da gestão dos recursos naturais.

Utilizando uma formulação talvez mais rigorosa, estar-se-ia perante a constatação, mais ou menos consciente, do incumprimento, em maior ou menor grau, das "grandes promessas" feitas desde o último quartel do século XIX: o fim dos conflitos entre Estados e das confrontações militares; o desenvolvimento dos "países pobres", antigos territórios coloniais, protectorados ou "nações tuteladas"; a validade dos "socialismos reais" e a inevitabilidade da vitória do comunismo; a eficácia definitiva do "capitalismo fordista" (ou keynesiano) e as ilimitadas possibilidades de aperfeiçoamento/expansão dos regimes democráticos/ /"Estados-providência"; a capacidade de compatibilizar crescimento económico e preservação dos equilíbrios ambientais.

Verificar-se-ia, ainda, a denúncia da forma como a quase totalidade dos sistemas ideológicos contemporâneos ("racionalistas" ou "irracionalistas") se procuraram legitimar através da participação nos e/ou da

"A destruição do passado - ou melhor, dos mecanismos sociais que veiculam a nossa experiência pessoal à das gerações passadas - é um dos fenómenos mais característicos e lúgubres do final do século XX. Quase todos os jovens de hoje crescem numa espécie de presente contínuo, sem qualquer relação orgânica com o passado público da época em que vivem. Por isso os historiadores, cujo ofício é lembrar o que os outros esquecem, tornam-se mais importantes que nunca no fim do segundo milénio." (E. Hobsbawm, 1996, p. 15) 
instrumentalização dos sucessos alcançados e do prestígio obtido pelas ciências e pelas tecnologias entretanto autonomizadas ("cientismos"); a recusa, tanto das reivindicações de superioridade absoluta do discurso científico sobre todas as outras leituras do (ou a propósito do) real, como das correspondentes pretensões de objectividade e indiscutibilidade.

Correndo, embora, o risco de esquematizar, considera-se que, no universo dos edificadores e dos cultores do "paradigma pós-moderno" (por contraposição ao "paradigma moderno"), é viável, pelo menos no âmbito das ciências sociais, detectar a presença de duas perspectivas diferenciadas. Num dos casos prevalece a afirmação da subjectividade radical e, portanto, da equivalência das diversas leituras interpretativas; da validade exclusiva de metodologias que se baseiem em modelos "micro", em abordagens empíricas ou em "reconstituições matemáticas" da própria realidade; da improcedência dos conceitos teóricos de média e grande dimensão.

Estar-se-ia, assim, perante concepções menos operatórias, distantes de um "máximo de objectivação possível", em simultâneo (contraditoriamente) irracionalistas e cientistas - lembre-se a importância da formalização matemática na estratégia de afirmação das sucessivas 'escolas' neo-clássicas de pensamento económico e da New Economic History; arautos do fim da luta de classes, das ideologias e da história, negadoras da validade de sistemas "macro", apologistas da impossibilidade de compreensão totalizante e, em consequência, de intervenção "não-artificial" no sentido da transformação (parcial ou global) das "condições naturais" existentes 5

"In a fragmented world composed of 'de-centred subjects', where totalizing knoledges are impossible and undesirable, what other kind of politics is there than a sort of de-centred and intellectualized radicalization of liberal pluralism? What better escape, in theory, from a confrontation with capitalism, the most totalizing system the world has ever known, that a rejection of totalizing knowledge? What greater obstacle, in practice, to anything more than the most local and particularistic resistances to the global, totalizing 
Algo provocatoriamente, utiliza-se a expressão "neo-modernidade" para designar a segunda corrente. Uma tal escolha resulta do facto de, não esquecendo os elevados custos humanos e ambientais dos cientismos finalistas (ou teleológicos) e da arrogância tecnológica, a infinita diversidade e complexidade de qualquer objecto de estudo, a relatividade e precaridade de todo o discurso cognitivo, a necessidade e as vantagens de cruzar as diversas grelhas interpretativas e valorativas em presença, se acabar por retomar o essencial dos pressupostos do "paradigma moderno", agora sob a forma de um racionalismo (auto-)crítico.

O conhecimento científico é encarado como processo de aproximação objectivante à realidade por intermédio de uma experimentação baseada em instrumentos de natureza epistemológica, teórica e metodológica. Implica um constante esforço interdisciplinar de reflexão sobre e de aperfeiçoamento desses mesmos pré-requisitos. Dada a presença inevitável (constitutiva) dos vectores emocional e ideológico, pressupõe o controlo dos perigos e a potenciação das virtualidades respectivas. Sendo um "produto cultural" com fortes implicações sociais, obriga os investigadores, quer a definirem-se perante o que os rodeia - valores, interesses e poderes -, quer a procurar antever as aplicações e os "efeitos secundários" do seu trabalho'.

power of capitalism than the de-centred and fragmented subject? What better excuse for submitting to the force majeure of capitalism than the conviction that its power, while pervasive, has no systemic origin, no unified logic, no identifiable social roots?" (Cfr. E.M. Wood, 1996, p. 2)

' "O reconhecimento, pela razão, dos seus limites e a consequente institucionalização de diálogo com o não racional (o arracional e o irracional) não pode implicar indiscriminado respeito por todos os interlocutores nem por todo o discurso oponente. A razão deve manter toda a sua vitalidade crítica bem como a sua agressividade argumentativa face ao discurso mistificador, à crença, ao culto sistemático do mistério, à mistificação do real. $\mathrm{O}$ apelo goetheano à entrada de mais luz deve continuar a nortear a acção combatente da racionalidade, se bem que nesta nova fase, enriquecida pela consciência assumida dos erros oriundos de narcísicos sectarismos pretéritos, a razão 
Depois de uma certa euforia empirista e narrativista, coincidente com o auge do "pós-modernismo radical" mas, também, ampliada pela endémica desconfiança dos historiadores perante a necessidade da formalização teórica, tem sido possível retomar, eventualmente em novas bases, o debate acerca dos conceitos a adoptar no estudo das sociedades humanas localizadas no espaço e no tempo. A influência exercida por sociólogos como A.F.K. Organsky, Immanuel Wallerstein e Pierre Bourdieu constitui uma ilustração pertinente da hipótese de renovação (ou reconstrução) antes aventada.

Seriam exemplos relevantes porque investigadores proponentes de modelos - de grande, média e pequena dimensão - de carácter interpretativo e globalizante, estruturados com o propósito de contribuir para o entendimento, tanto de regas próprias de funcionamento/de modalidades de integração "da(s) partes(s) no todo", como das condições de evolução da realidade humana no seu conjunto. Se por um lado recusam veleidades cientistas, por outro assumem motivações (não apenas nem essencialmente mas também) ideológicas, a influência social e as eventuais derivações cívicas da actividade concretizada.

Tendo em conta a problemática em apreço e perante a maior notoriedade de Wallerstein ou de Bourdieu, cita-se o caso específico de The stages of politicai development. Obra de A.F.K. Organsky editada pela primeira vez em 1965 e redescoberta nos anos noventa pelos

tenha de assentar a sua autoridade na endógena capacidade de inteligência argumentativa e não em meios materiais de extermínio físico [...].

Trata-se agora de preencher o perigoso vazio ideológico, aberto nos últimos anos, com ideários estribados numa racionalidade dialéctico-complexa constitutiva do paradigma emergente superador do clássico modelo reducionista/dijuntivo/a-histórico, crente numa ordem simples [...]. Importa fazer ver, contrariando ideias em voga, que o mundo instável e incerto revelado na caminhada cognitiva da indagação científico-racional não é caos ameaçador, é sim génese de nova ordem complexa que se substitui à ordem substante e simples típica do paradigma em ocaso." (Cfr. J.M.F. Branco, 1996, p. 29) 
estudiosos da história político-institucional contemporânea - oriundos da história, do direito, da ciência política, da sociologia e da antropologia políticas, etc. -, ensaia uma abordagem dialéctica das influências mútuas que se teriam estabelecido entre níveis de desenvolvimento prévios, interesses e estratégias de modernização dominantes, correntes ideológicas e regimes políticos consolidados ${ }^{7}$.

Interessaria, ainda, lembrar quais são, de acordo com esse eventual "neo-modernismo" (a vertente "racionalista crítica" do pós-modernismo), os aspectos definidores e as principais funções dos conceitos teóricos. A semelhança do que acontece nas ciências e tecnologias ditas "exactas", também nas suas congéneres "sociais e humanas", por maioria de razão, não estariamos, antes de mais, nem frente a somatórios das características de uma determinada realidade histórico-concreta, nem perante agregados de meras (simplistas) relações de causa e efeito apenas no interior de um objecto de estudo particular e limitado ("sectorial").

Trata-se, inversamente, de "contra-realidades" abstractas, elaboradas a partir de observações empíricas iniciais e utilizadas enquanto revelarem níveis aceitáveis de operatividade; instrumentos destinados a auxiliar no esforço de compreensão de regionalidades específicas (delimitadas pelo observador de forma artificial) e das correspondentes modalidades

"The primary function of government in this second stage of political development is to permit and aid economic modernization. All three varieties of government bourgeois, Stalinist, and fascist - have done this, and though the differences in the three systems are large and significant, all are alike in performing three important taks wich help the nation industrialize.

First, they make possible a shift of political power from the hands of the traditional elite to the industrial managers who wish to modernize the economy. The Stalinist system acts swiftly, by eliminating the old aristocracy in its initial revolution. The bourgeois system shifted more gradually, with the bourgeoisie slowly gaining the upper hand over the traditional aristocracy and then sharing its power with the masses. Under fascism the old landed gentry helded on most tenaciously, ruling jointly with the new industrial elite throughout the fascist period but losing out in the end." (Cfr. A.F.K. Organsky, 1965, p. 10) 
de participação no processo de estruturação, reprodução ou desintegração do social global; componentes do método científico enquanto auxiliares na elaboração de hipóteses e na verificação da eficácia cognitiva das mesmas ${ }^{8}$.

Na qualidade de "tipos ideais", no sentido weberiano da expressão, não têm correspondência com vertentes de qualquer sociedade efectivamente existente, mas possibilitam tentativas de medição das diferenças e semelhanças, dos graus de concretização e níveis de dominação alcançados, das continuidades e roturas, dos desvios ou aproximações efectuados; contribuem para o estabelecimento (a eventual descoberta) de correlações entre redes amplas de condicionalismos explicativos; viabilizam estudos comparativos sobre objectos próximos ou distantes (quanto à sua identidade ou localização no espaço e no tempo) ${ }^{9}$.

\section{Autoritarismo, fascismo e totalitarismo}

Tendo em conta os pressupostos atrás explicitados, encara-se como operativa a grelha de análise, válida para o conjunto da Época Contemporânea, integrante das seguintes categorias no que concerne a ideologias, movimentos/partidos e regimes políticos: liberalismo conservador,

8 "This is the difficult dialectic between historical specificity and the always present logic of historical process that historical materialism asks us to comprehend. It requires [...] a conception of the 'economic', not as a 'regionally' separate sphere wich is somehow 'material' as opposed to 'social', but rather as itself irreducibly social — indeed, a conception of the 'material' as constituted by social relations and practices. Furthermore, the 'base' - the process and relations of production - is not just 'economic' but also entails, and is embodied in, juridical-political and ideological forms and relations that cannot be relegated to a spatially separate superstructure." (Cfr. E.M. Wood, 1996, p. 61)

Cfr., nomeadamente. P. Bourdieu, 1989; J.M.F. Branco, 1996; A. Castro, 1989; E. Fernandez Clemente, 1995; C. Forcadell Alvarez, 1995; P. Nora, 1989; A.S. Nunes, 1970; A.J.A. Nunes, 1995; A.F.K. Organsky, 1965; F. Rosas, 2000; B.S. Santos, 1987; I. Wallerstein, 1974-1989; E.M. Wood, 1996. 
monarquias autocráticas, autoritarismo, socialismo, demoliberalismo, comunismo (anarquista, leninista, estalinista), fascismo, democracia com períodos revolucionários, de reacção ou contra-revolução, estabilidade e desagregação; modalidades não-totalitárias e sistemas muito ou pouco totalitários.

Mesmo considerando apenas a sua aplicação ao estudo do século XX e de países europeus, americanos ou asiáticos, são inúmeros os debates que envolvem, sobretudo, as noções de autoritarismo, fascismo e totalitarismo - por motivações tanto de ordem científica como ideológica. O nível de controversialidade aumenta quando se introduz a problemática da comparação entre as formas extremas de fascismo (o nacional-socialismo alemão, o militarismo japonês) e as modalidades mais violentas de comunismo (o bolchevismo soviético, o maoismo chinês, o regime norte-coreano e o polpotismo cambodjano $)^{10}$.

No plano científico, obstáculos resultantes da natureza intrinsecamente demagógica, mutável e, ao mesmo tempo, intransigente dos fascismos; do carácter ultra-nacionalista (muitas vezes expansionista) e a-internacionalista das correntes de extrema-direita em cada país ou nação, o que dificultava o estabelecimento de relações públicas com as suas congéneres e, mais ainda, a criação de uma "internacional" ou de um único bloco político-militar; da sistemática associação dos "movimentos", alas radicais por excelência, com outros sectores (conservadores) da direita aquando do acesso ao ou da conquista do poder; das diferentes características sociais globais e condicionalismos externos prevalecentes em cada Estado, os quais estiveram na origem de variadas formas de estruturação e actuação dos regimes, quer em termos internos, quer internacionais; da presença simultânea de interesses e valores tradicio-

${ }^{10}$ Cfr., entre outros, S. Berstein, 1992; B. Droz, 1988-1993; F. Furet, 1998; Le livre noire [...], 1997; A.F.K. Organsky, 1965; S.G. Payne, 1980; J.P. Pereira, 1999-2001; H. Rousso, 1999; Z. Sternhell. 1995; R. Tamames, 1986; H. Thomas, s.d. 
nalistas e modernizadores, "irracionalistas" e "pragmáticos"; da longa duração de algumas dessas experiências políticas, com as correspondentes mutações parcelares e mais ou menos superficiais (ou cosméticas); da impossibilidade de acesso aos arquivos e de concretização de projectos de investigação em história recente ou em outras ciências sociais; da utilização simultânea destes vocábulos na luta política - desde o pós-Primeira Grande Guerra até aos nossos dias; etc.

Em termos ideológicos, perante a necessidade reforçada de, no âmbito da "guerra fria", manter integrados no "bloco capitalista" (associados ao "mundo livre") os regimes ditatoriais de direita não-expansionistas; devido aos propósitos revisionistas ou, mesmo, negacionistas de personalidades e entidades colectivas directa ou indirectamente relacionadas, quer com essas estruturas de poder e esses valores, quer com uma determinada concepção de "inquestionável grandeza" e "continuidade a-histórica" do Estado, da Nação, de instituições e organizações - Forças Armadas, universidades, igrejas, associações patronais, empresas, etc; a dificuldade da maioria dos intelectuais "de esquerda" em geral e dos marxistas em particular em reconhecer, em discordar ou em combater muitas das características da generalidade dos partidos comunistas e dos "socialismos reais" (no essencial de tipo "estalinista")".

" "La victoria de las fuerzas aliadas, en 1945, y, consecuentemente, el fin de los sistemas fascistas principales y el comienzo de la guerra fría, reorientará la conceptualización del termino totalitario. Hasta ahora - aunque no unánimemente — el paradigma del totalitarismo era el fascismo; a partir de 1945, el discurso variará: el paradigma totalitario será ya el marxismo-leninismo y, en cuanto formalizacion jurídica, los países del "socialismo real" [...]. El autoritarismo se entenderá, genéricamente, como aquella categoría que conforma regímenes no-democrático-liberales, pero anti-marxistas beligerantes, y que, conyunturalmente, por razones de guerra fría o riestos revolucionarios podrían ser aliados vergonzantes [...]. En esta reclasificación [...] habrá "dictaduras amigas" y "dictaduras enemigas", con naturaleza inmannente (totalitarismo comunista) y naturaleza conyuntural (autoritarismo pos-fascista) [...]. Las estrategias políticas gubernamentales [...], resultado de la confrontación Este-Oeste, tendrán, de esta manera, una traducción ideológica y académica." (Cfr. R. Morodo, 1995/1996, p. 205/206) 
Simplificando, inevitavelmente, um património de reflexão rico e complexo, identificar-se-ia a existência de duas correntes principais. A primeira, taxionomista ou restritiva, é maioritária entre os cientistas sociais. Implica a aceitação da validade teórica de uma metodologia que pressupõe a separação de um determinado objecto de conhecimento do seu contexto histórico para se lhe aplicar uma tipologia ou grelha de características-tipo absolutas e universais - sobretudo focalizada em vectores de natureza ideológica e político-institucional.

De acordo com este ponto de vista, quase não teriam existido regimes fascistas, uma vez que, na maioria dos casos (incluindo, segundo alguns autores, a própria Itália de Benito Mussolini), os "movimentos" perderam o carácter "radical, de mobilização e revolucionário" no processo de ascensão ao poder, acabando por ser absorvidos pelos sectores conservadores (tradicionalistas ou modernizadores); dependeram do apoio de forças de ocupação germânicas ou italianas; nunca chegaram a desempenhar um papel dominante ou, sequer, significativo.

Apenas um Estado fascista teria assumido dimensão totalitária, o Terceiro Reich nacional-socialista. Ao Japão do Imperador-Deus e dos Governos militares faltaria o movimento/partido, uma "ideologia revolucionária" e a mobilização de massas. Haveria uma incompatibilidade ontológica entre a estruturação de um sistema totalitário e a permanência numa dada sociedade de outros poderes que não o partido/Estado - Forças Armadas, igrejas, elites administrativas, económicas ou culturais.

Antes, durante e após a Segunda Guerra Mundial, tal como em múltiplos outros casos, também na Hungria do Almirante Miklós Horthy, na Polónia do General Josef Pilsudski, no Portugal de Oliveira Salazar, na Áustria de Engelbert Dollfuss, no Brasil de Getúlio Vargas, na Roménia de Carol II, na Espanha do General Francisco Franco, na Argentina do Coronel Juan Péron - para já não referir a Eslováquia do Monsenhor Josef Tiso ou a França do Marechal Henri Pétain (a Croácia de Ante 
Pavelitche constituiria uma excepção) -, teriam vigorado 'apenas' ditaduras moderadas e burocráticas, autoritarismos conservadores e paternalistas, corporativismos católicos ou ortodoxos ${ }^{12}$.

Segundo a perspectiva dos estudiosos minoritários, dialéctica ou genérica, só faz sentido aplicar a noção restrita de fascismo ao estudo de ideologias e movimentos, uma vez que muitos dos regimes ditatoriais de direita que se formaram a partir da década de vinte integraram, simultaneamente, em graus diferentes de acordo com a anterior evolução histórica nacional, as conjunturas internas e os enquadramentos internacionais, características "radicais" e "conservadoras". O conceito de fascismo assumiria, assim, um estatuto semelhante ao dos que representam os outros sistemas - não apenas ideológicos e político-institucionais mas sociais globais - existentes desde as revoluções liberais e do início do processo de afirmação da hegemonia da economia-mundo capitalista (desde o último quartel do século XVIII).

Para que um regime seja classificado como totalitário de tipo fascista, 'bastaria' que, a partir de um movimento/partido ou do Estado (no seguimento de eleições, golpe militar, etc.), com o apoio (paritário ou subordinado) de outros poderes e/ou através da respectiva anulação, se tivesse procurado e conseguido impor uma ditadura de direita - antidemoliberal e anti-socialista, nacionalista e imperialista ou colonialista, centralista e intervencionista, capitalista mas corporativista e autárcica ou proteccionista -, baseada numa concepção maniqueísta e regeneradora/historicista de sociedade; no monopólio da actividade político-ideológica, no controlo do aparelho de Estado e da sociedade civil, na

Cfr., nomedamente, Annales [...], 1988; S. Berstein, 1992; M. Blinkhorn, 1990; J.L. Cornelias, 1990; M.B. Cruz, 1988; M.B. Cruz, 1998; A. Ferro, 1933; C. Gaspar, 2000; J. Georgel, 1999; R. Griffin, 1996; S.J. Lee, 1996; Y. Leonard, 1998; J. Medina, 2000; P. Milza, 1992; S.G. Payne, 1980; S.G. Payne, 1983; S.G. Payne, 1987; A.C. Pinto, 1990; A.C. Pinto, 1992; A.C. Pinto, 1994; A.C. Pinto, 1998; A. C. Pinto, 2001; R. Preto, 1933; N. Valério, 1993. 
diabolização/supressão das oposições e alternativas, na reconversão e criação de instrumentos de repressão e enquadramento das populações, no culto de um "Chefe" supremo e carismático.

$\mathrm{O}$ racismo exterminacionista ou o nacionalismo exacerbado, a repressão selectiva ou o terror de massas, o expansionismo militarista ou o colonialismo anacrónico, o "neo-paganismo" (centrado na "raça" e/ou no Estado) ou o providencialismo religioso, os voluntarismos tradicionalistas ou modernizadores, o elitismo/mobilização parcial e ocasional ou a politização/alienação integral e permanente da vida colectiva, etc., apesar de serem vectores fundamentais das diversas vivências histórias concretas, não integrariam o conjunto das características definidoras do modelo teórico de totalitarismo ${ }^{13}$.

Face aquele conceito, a noção de autoritarismo implicaria diferenças significativas em termos de grau e de natureza. Pressupõe, por um lado, limitações a liberdades e direitos nucleares em sistemas demoliberais ou democráticos. Resulta, por outro, na manutenção de níveis relativamente elevados de pluralismo, tanto no interior do regime vigente, como na sociedade em geral. Tem por objectivo intervir, de forma expedita ("vanguardista"), no sentido da alteração - modernizadora ou neo-tra-

3 "Foi justamente das grandes linhas, comuns a todos os movimentos e regimes de que falámos, que extraímos a confirmação da existência de um húmus cultural e de uma contingência histórica que permitiram a realização de experiências que não foram isoladas nem fragmentárias e que podem ser referidas a uma única ideia-força quaisquer que depois tenham sido as suas diversas traduções nos respectivos contextos políticos e sociais específicos. Procurámos também sublinhar que o elemento comum a estas experiências não pode ser identificado unicamente no aspecto negativo, nos alvos contra os quais esses vários movimentos e regimes tomavam posições de rejeição ou de ataque [...]. A luta contra o socialismo e contra o pluralismo político e social assume em toda a parte o duplo aspecto de totalitarismo no interior - a unicidade do partido de Estado, a função carismática do chefe como símbolo da hierarquização vertical, a exclusão de todo e qualquer "outro", de toda e qualquer diversidade - e de totalitarismo para o exterior, ou seja: da pretensão de superioridade, do primado como potência e como civilização, do extremismo nacionalista e do imperialismo." (Cfr. E. Collotti, 1992, p. 218/219) 
dicionalista, à esquerda ou à direita - de uma determínada situação, encarada como bloqueada e incapaz de auto-renovação ou em perigo de rotura. Não visa, no entanto, alcançar, nem o advento exclusivista de um movimento/ partido "de novo tipo" e correspondente desmantelar de todas e quaisquer actividades de oposição ou alternativa, nem a transformação do aparelho de Estado num instrumento de domínio absoluto da sociedade civil ${ }^{14}$.

\section{As experiências portuguesa e espanhola}

Partindo do princípio de que é sempre possível enumerar múltiplas discrepâncias entre toda e qualquer realidade e os conceitos utilizados no seu estudo, visando a elaboração de um discurso explicativo de natureza historiográfica, sociológica, antropológica, económica, etc., opta-se por considerar que, apesar das transformações resultantes da evolução dos condicionalismos internos e externos, no Portugal dos anos de 1932 ou 1933 a 1974 e na Espanha franquista (1936 ou 1939 a 1975), vigoraram regimes de tipo fascista, tendencialmente totalitários.

Uma tal escolha não ignora, pois, antes pelo contrário, as tensões que, em cada um ou em ambos os Estados peninsulares, opunham, no seio das próprias bases sociais e políticas de apoio às ditaduras, radicais e conservadores, modernizadores e tradicionalistas, irredentistas e moderados, colonialistas e europeístas, monárquicos e republicanos, católicos e anticlericais ou laicos, centralistas e descentralistas ou

${ }^{4}$ Cfr., entre outros, S. Cerqueira, 1973; E. Collotti, 1995; M.B. Cruz, 1982a; M.B. Cruz, 1982b; M.B. Cruz, 1985; O Estado Novo [...], 1987; O fascismo em Portugal [...]. 1982; J. George1, 1974; J. Georgel, 1985; M. Loff, 1997; M. Lucena, 1984; M. Lucena, 1994; M.-A. Macciocchi, 1976; R. Morodo, 1995/1996; E. Noite, 1969; J.P.A. Nunes, 1993a; J.P.A. Nunes, 1993b; C. Oliveira, 1991;A.F.K. Organsky, 1965;P.Preston, 1995; D.L. Raby, 1990; A Revolução continua [...], 1943; F. Rosas, 1989; F. Rosas, 2001; A.O. Salazar, 1945-1967; J. Sánchez Cervelló, 1993; L.B. Schirò, 1988-1990; L.R. Torgal, 1993; Vértice [...], 1989; S.J. Woolf, 1978. 
autonomistas, defensores de um máximo intervencionismo económico-social por parte do Estado e associações patronais, organizações milicianas e Forças Armadas, etc. Acarreta, igualmente, como não poderia deixar de acontecer, implicações diversas nos planos científico-ideológico e cívico-ético.

Estará, eventualmente, em causa, quanto à produção de conhecimentos, o acesso aos "testemunhos do passado" - antes de mais à documentação escrita não-impressa, gráfica e audio-visual (pública e particular), dada a forte tutela institucional que sobre a mesma é exercida; a compreensão do(s) peso(s) e da(s) lógica(s) de integração do(s) fascismo(s) na época contemporânea; a possibilidade de estabelecer comparações e de detectar influências entre as várias evoluções nacionais nos diversos períodos; o relevo atribuído aos vectores de caracterização mais significativos ou o respectivo branqueamento.

No que concerne à divulgação cultural, trata-se de garantir (ou não) aos cidadãos acesso a informação e a propostas interpretativas esclarecedoras (desalienantes) acerca da história recente do seu país, da Europa e do Mundo; de estimular ou bloquear estudiosos, entidades, iniciativas e publicações que se proponham intervir com esse objectivo. Um tal dilema ocorre, no entanto, em sociedades que se pretendem democráticas, cuja vitalidade depende, entre outros factores, de "opiniões públicas" que se relacionem, de forma consciente e crítica, com as respectivas memórias históricas e identidades.

O processo de estruturação e consolidação do Estado Novo ocorreu após as dificuldades e incapacidades das versões monárquica e republicana de um sistema demo-liberal; depois da instabilidade e da multiplicidade de alternativas potenciais existentes no âmbito da Ditadura Militar (1926-1932), regime autoritário que acabou por se revelar transitório. A solução vencedora foi construída, de modo simultaneamente casuístico e pré-concebido, por um amplo conjunto de personalidades, forças 
político-sociais e correntes ideológicas chefiadas e geridas por António de Oliveira Salazar.

Para além da repressão "das esquerdas revolucionárias" e dos defensores (mais ou menos críticos) da continuidade do figurino demoliberal ou da evolução do mesmo no sentido da democracia, a vitória do salazarismo implicou a exclusão, quer de sectores republicanos conservadores apologistas de um pós-28 de Maio como mero "interregno regenerador" da Primeira República, quer dos dirigentes e simpatizantes "intransigentes" do Centro Católico Português, da Causa Monárquica, do Integralismo Lusitano e do Movimento Nacional-Sindicalista.

A ditadura manteve a fidelidade das "forças de segurança" (com destaque para a polícia política) até 1974. Pelo menos nos anos trinta e durante a década de cinquenta - a conjuntura da Segunda Guerra Mundial esteve na origem da primeira crise séria do sistema -, contou com o apoio e a participação do essencial das Forças Armadas e da administração pública, dos sectores patronais e das classes médias, das elites locais e do mundo rural (com a excepção parcial do Ribatejo e do Alentejo), dos meios universitários e de muitos dos intelectuais. Foi, ainda, aceite pelas potências internacionais relevantes do "bloco capitalista", salvo a Espanha nos anos rojos da Segunda República (1931-1933 e 1936).

Constatação idêntica poderá ser aventada no que diz respeito à Igreja e à "acção católica", apesar de algumas dissidências individuais e de grupos restritos; de rivalidades e desacordos, ultrapassados de forma negociada e resultantes, quer da dimensão/diversidade e dos compromissos europeus ou mundiais do catolicismo (lembrem-se os exemplos das democracias-cristãs francesa, belga e italiana), quer das ambições "neo-teocráticas", ou seja, também totalitárias de algumas das elites eclesiásticas e leigas - formalmente abandonadas, apenas, depois do Concílio Vaticano II (1962-1965) ${ }^{15}$. 
O Nuevo Estado resultou, por sua vez, da vitória dos nacionales na Guerra Civil de Espanha (1936-1939). Seguiu-se ao rotativismo demoliberal monárquico da Restauración (1875-1923), intercalado, embora, por diversas tentativas regeneracionistas de cariz mais ou menos semiditatorial; ao regime autoritário liderado pelo General Miguel Primo de Rivera y Orbaneja com a chancela de Afonso XIII (1923-1930); à Segunda República democrática (1931-1935), com maiorias parlamentares, Governos e políticas de centro-esquerda e de centro-direita; à conjuntura em simultâneo pré-revolucionária e contra-revolucionária vivida nos meses de Janeiro a Julho de 1936.

A reprodução 'flexível' dos equilíbrios de forças internos e a progressiva aceitação numa "comunidade internacional" marcada pela lógica da "guerra fria", viabilizaram a sobrevivência da ditadura até 1975. Em alguns casos até ao fim dos anos cinquenta, noutros mesmo depois da morte do General Francisco Franco Bahamonde (a 20 de Novembro de 1975), verificou-se o empenhamento da quase totalidade dos militares e agentes das forças policiais, da grande burguesia e da nobreza terrate-

Clarence-Smith, 1990; J. Cornwell, 2000; M.B. Cruz, 1982b; M.B. Cruz, 1985; M.B. Cruz, 1988; M.B. Cruz, 1998; J.P. D'Assac, 1962; O Estado Novo [...], 1987; L. Farinha, 1998; O fascismo em Portugal [...], 1982; J.M. Ferreira, 1996; A. Ferro, 1933; T. Gallagher, 1983; C. Gaspar, 2000; J. Georgel, 1985; J. Georgel, 1999; H.P. Janeiro, 1998; E. C. Leal, 1999; M. Loff, 1997; M. Loff, 2000; A. Louçã, 2000; M. Lucena, 1976; J. Madeira, 1996; J. Marcadé, 1988; F. Medeiros, 1978; F. R. Meneses, 2000; M. F. Mónica, 1978; J.P.A. Nunes, 1993a; J.P.A. Nunes, 1993c; J.P.A. Nunes, 1995a; J.P.A. Nunes, 1995b; J.P.A. Nunes, 1999b; J.R. Ó, 1999; C. Oliveira, 1985; C. Oliveira, 1987; C. Oliveira, 1991; H.J. Paulo, 1994; M.F. Patriarca, 1995; J.P. Pereira, 1999-2001; I.F. Pimentel, 2000; A.C. Pinto, 1994; A.C. Pinto, 1998; A.C. Pinto, 1997; A. C. Pinto, 2001; G.J. Pita, 1996/1997; R. Preto, 1933; D.L. Raby, 1990; A. Reis, 1991; Revista de História das Ideias [...], 1994 e 1995; A Revolução continua [...], 1943; M.I. Rezola, 1999; M.C. Ribeiro, 1995; N.L. Rodrigues, 1996; F. Rollo, 1994; F. Rosas, 1989; F. Rosas, 1990; F. Rosas, 1992; F. Rosas, 1994; F. Rosas, 1996; F. Rosas, 1998; F. Rosas, 2000; F. Rosas, 2001; Salazar e o salazarismo [...], 1989; A.O. Salazar, 1945-1967; N. S. Teixeira, 2000; A.J. Telo, 1977; A.J. Telo, 1980-1984; A.J. Telo, 1996; A.J. Telo, 2000; H. Torre Gómez, 2000; J.C. Valente, 1999; Vértice [...], 1989. 
nente, do aparelho de Estado, da Igreja e da "acção católica", dos pequenos e médios proprietários rurais; de parcelas significativas das classes médias, dos intelectuais e universitários.

Uma tal longevidade foi assegurada apesar dos - por vezes, também, devido aos - elevados níveis de repressão concretizados; da intervenção de outros Estados fascistas durante a Guerra Civil (Portugal, Itália, Alemanha); das tentações imperialistas e da solidariedade para com o Eixo manifestadas nos primeiros anos da Segunda Guerra Mundial; da forte mobilização política e da bipolarização atingidas na década de trinta - sufrágio universal masculino desde 1890 e sufrágio universal feminino a partir de 1933, organizações sindicais e patronais, partidos políticos e correntes ideológico-culturais com influência de massas, âmbito nacional e conexões internacionais; do contraste entre os níveis de desenvolvimento antes alcançados e a degradação das condições de vida para muitos milhões de espanhóis até ao início dos anos sessenta; do conflito entre a lógica unitária e as reivindicações autonomistas na Catalunha, País Basco e Galiza; das pressões no sentido da reinstauração imediata da monarquia - autoritária primeiro, demo-liberal depois ${ }^{16}$.

Entre as correntes ideológicas e as soluções organizativas que terão influenciado a "Revolução Nacional" salazarista, é legítimo salientar os projectos de regeneracionismo do último quartel do século XIX - o cesarismo de Oliveira Martins e de outros dissidentes do Partido Progressista, agregados no grupo da "Vida Nova"; o "cortar a direito" dos militares que chefiaram as "campanhas de pacificação" nas colónias

${ }^{16}$ Cfr., entre outros, J. Catalan, 1995; J.L. Cornelias, 1990; J.P. D'Assac, 1962; M. Espadas Burgos, 1988; R. García Pérez, 1994; J. Georgel, 1974; J. Georgel, 1999; Historia de España [...], 1986; Informe para la Comisión [...], 1998; J.C. Giménez Redondo, 1996; Le livre noire [...], 1997; L. Martínez-Risco Daviña, 1994; G. Pasamar Alzuria, 1991; S.G. Payne, 1987; P. Preston, 1995; J. Sanchez Cervelló, 1993; R. Tamames, 1986; H. Thomas, s.d.; H. Torre Gómez, 1998; H. Torre Gómez, 2000; F. Umbral, 1994; M. Vázquez Montalbán, 1992. 


\section{João Paulo Avelãs Nunes}

africanas, com destaque para Mouzinho de Albuquerque e o apoio de Carlos I, etc.; as experiências ditatoriais simbolizadas por João Franco (1906-1908) e Sidónio Pais (1917/1918); o Nacionalismo Lusitano de João de Castro Osório e a "direita das realizações" - a União Liberal Republicana de Francisco Cunha Leal, a União dos Interesses Económicos, entre outros; o Nacional-Sindicalismo de Francisco Rolão Preto como expoente máximo de uma direita radicalizada (Integralismo Lusitano, Cruzada Nacional D. Nuno Alvares Pereira, Acção Realista Portuguesa, Liga Nacional 28 de Maio, etc.); a democracia cristã conservadora - hierarquia da Igreja, "acção católica", Centro Católico Português; o maurrasianismo da Action Française e o fascismo italiano; o modernismo e o futurismo; o historicismo dos ciclos de grandeza/ /decadência e o organicismo nacionalista/colonialista - corporativista e confessional, eurocêntrico e racista, anti-demoliberal e anti-socialista, "anti-plutocrático" e anti-semita.

Nas décadas de 1910 e 1920, Portugal foi um país marcado por profundas contradições, grande instabilidade e múltiplos vectores de conflito. Esta avaliação pode ser sustentada mesmo reconhecendo que a maioria dos ex-combatentes da Primeira Grande Guerra acabaram por não ser enquadrados pelo ultra-nacionalismo - coube ao Partido Democrático a defesa do envolvimento directo na "Frente Ocidental"; que eram relativamente baixos, fora das principais cidades, os níveis de desenvolvimento económico e sócio-cultural, bem como os graus de participação política; que não chegaram nunca a existir o sufrágio universal, partidos políticos de massas, confederações sindicais e associações patronais com implantação nacional.

Quanto às clivagens mais relevantes, lembram-se as que opunham republicanos e monárquicos, laicos e católicos, movimento operário e grande burguesia (urbana ou rural); apologistas da participação na guerra, defensores de uma intervenção militar apenas nas colónias, monárquicos 
germanófilos, anti-militaristas das várias correntes socialistas; industrialistas (proteccionistas, favoráveis ao reforço da intervenção estatal na "esfera económica", arautos da modernização/concentração empresarial) e ruralistas/porta-vozes dos interesses comerciais e financeiros (livre-cambistas), centralistas e regionalistas; a "acção directa" de esquerda e a violência miliciana de centro-direita, o sindicalismo revolucionário e a repressão autoritária por parte dos Governos e do aparelho de Estado.

Acrescentem-se, também, a crispação frente às ameaças de perda das colónias e ao "perigo espanhol" (real ou imaginário, anexionista ou federalista), a crónica instabilidade parlamentar/governamental e a incapacidade de concretização de reformas, as sequelas económico-sociais e financeiras da participação no conflito e da sucessão de crises do pós-Primeira Grande Guerra, os receios provocados e as esperanças suscitadas pela Revolução Bolchevique de 1917 e pelo conjunto de fenómenos de "perturbação da ordem" então ocorridos em diversos outros países (Alemanha, Hungria, Bulgária, Itália, França, Reino Unido, etc.).

É hoje aceite que, na "Metrópole", o Estado Novo não recorreu ao terror de massas - avaliação que deixa de ser válida quanto às populações ("indígenas" ou "assimiladas") dos territórios coloniais. Terá, igualmente, optado por limitar o esforço de mobilização política aos centros urbanos ou a algumas ocasiões especiais, por controlar as tendências de radicalismo ideológico e miliciano existentes no seu seio (em 1933/1934, após 1939/1940). Respeitou, mesmo que apenas em parte, a "autonomia convergente" de 'parceiros' como os quadros superiores do aparelho de Estado, a Igreja e a "acção católica", as estruturas patronais sobreviventes ao processo de corporativização coerciva - Associação Central da Agricultura Portuguesa, Associação Industrial Portuguesa, Associação Industrial Portuense, Associações Comerciais de Lisboa e Porto. Adoptou, também, uma lógica "gradualista e pragmática" de introdução de muitas 
das transformações "regeneradoras"17.

Apesar da estratégia de sistemática mitificação e glorificação da personalidade e do contributo do "Chefe" no âmbito e para o sucesso da "Revolução Nacional", António de Oliveira Salazar recusou, ainda, um exercício abertamente demagógico e coreográfico do poder. Tal não significa, no entanto, que o regime não se tenha afirmado como alternativa totalitária e "paliengenética" - na acepção de Roger Griffin ${ }^{18}$ - ao "caos demo-liberal" e à "malignidade absoluta do socialismo/comunismo"'

No que diz respeito aos principais vectores de caracterização da ditadura portuguesa, apontam-se a Constituição Corporativa de 1933 e

${ }^{17}$ "Não compare, digo-lhe mais uma vez, o caso italiano com o português. Mussolini teve logo ao seu lado, com a mola da ocupação das fábricas, trezentos mil camisas negras. Com uma força inicial dessas toda a força é possível... Em Portugal, essa obra de renovação total, mesmo que ela fosse possível e legítima, não seria aguentada pela Nação... Somos um país pobre, doente, que não suporta facilmente grandes injecções de sangue novo... Vamos devagarinho, passo a passo." (Cfr. A. Ferro, 1993, p. 148)

${ }^{18}$ Cfr. R. Griffin, 1996.

19 "Contra o espírito delirante da luta de classes, contra o conservadorismo que poderia tentar impedir um alto ideal de justiça e de paz social, a Legião ergue a bandeira activa da sua mística. A Legião é uma força revolucionária disposta a corresponder com energia e entusiasmo à interrogação do Chefe: "E eu pergunto se, enquanto houver uma nuvem de perigo externo, um germe de desagregação interior, um português sem trabalho ou sem pão, a Revolução não há-de continuar?". A milícia ajudou a derrubar e não permite que se reergam os velhos ídolos do anti-clericalismo, da plutocracia, dos internacionalismos pseudo-humanitários, da demagogia anárquica; contra eles levanta bem alto o estandarte das suas certezas: a fé, a família, a moral cristã, a autoridade, a liberdade da terra portuguesa.

Porque não são apenas o comunismo e o anarquismo que tentam insidiosamente atacar e subverter o nosso renascimento; o derrotismo, a crítica sistemática, a insinuação torpe, o vício doentio de imaginar para tudo "bastidores" suspeitos e inconfessáveis todas as taras e todos os defeitos de um passado sem grandeza - têm sido combatidos pela Legião e não voltarão a gozar um momento só de trégua, quanto mais um vislumbre de vitória. Adquiriu um sentido político a frase do romancista: "é preciso matar este morto". Tudo o que possa lembrar, tudo o que possa fazer reviver o abismo de que escapámos tem na Legião um inimigo infatigável e que não cede." (Cfr. A Revolução continua $[\ldots], 1943$, p. 54/55) 
o Acto Colonial (1930), acompanhados por diversa outra legislação regulamentadora e de natureza mais explicitamente repressiva. Presentes estavam, ainda, um colonialismo - imposição da "lógica imperial" nas relações entre "Metrópole" e "Colónias", restabelecimento de uma "mística civilizadora" com Armindo Monteiro e outros, a Agência Geral das Colónias, a Sociedade de Geografia de Lisboa, a Primeira Exposição Colonial Portuguesa - e um centralismo estruturantes (reforço do fenómeno tradicional do clientelismo e do poder arregimentador dos Governadores Civis, governamentalização e corporativização da administração provincial, concelhia e das freguesias); o predomínio do Executivo sobre a Assembleia Nacional e a Câmara Corporativa; a função (na prática) subalterna, essencialmente simbólica e de legitimação junto das Forças Armadas por parte dos Presidentes da República ${ }^{20}$.

Cita-se o carisma, a indiscutida liberdade de decisão e a função essencial desempenhada por Oliveira Salazar, Presidente do Conselho fundador e vitalício, o qual acumulou diversos outros cargos e mecanismos de intervenção: Ministro das Finanças (1928 a 1940), Ministro das Colónias (1930), Ministro da Guerra (1932 e 1936 a 1944), Ministro dos Negócios Estrangeiros (1936 a 1947), Ministro da Defesa Nacional (1961/1962); tutela directa sobre a Subsecretaria de Estado das Corporações e Previdência Social, a PVDE/PIDE, a Legião Portuguesa e o SPN/SNI; suspensão quase total das reuniões do Conselho de Ministros

${ }^{20}$ "Têm razão os que notam essa diferença, a diferença que vai do relatório para o texto da Constituição - concorda serenamente o Dr. Salazar. Nessa distância, porém, não há contradições. Ela foi consciente. O relatório é o ideal, a finalidade, aquilo para que marchamos. O projecto é a realidade possível dentro do nosso momento político. O óptimo é inimigo do bom [...].

A nova Constituição tem de ser, simultaneamente, uma realização e um programa...

- Uma Constituição que traga em si própria a semente da sua renovação - tento resumir.

- Exactamente... - diz o Dr. Salazar aprovando a soma." (Cfr. A. Ferro, 1933, p. 54/ 155). 
e relacionamento individual/hierárquico com os responsáveis pelas diversas pastas governamentais; liderança da União Nacional e indicação dos "candidatos oficiais" às 'eleições' para a Presidência da República.

Identificam-se a União Nacional (Acção Nacional Popular entre 1970 e 1974) como partido único e a Legião Portuguesa enquanto estrutura miliciana; a transformação das eleições em meros actos plebiscitários ou, a partir de 1945, em cedências cosméticas e fraudulentas (temporárias e parciais) a pressões internas e a pseudo-exigências externas de "evolução contro-lada"; o secretismo e a opacidade administrativa enquanto princípios essenciais de funcionamento do Governo e do aparelho de Estado em geral - detectáveis, por exemplo, no modo como era produzida e arquivada ou destruída a documentação oficial.

Destaca-se o papel desempenhado pelas Forças Armadas e pelas polícias como garantes da ditadura; a posição central do omnipresente sistema de "justiça política" - Polícia de Vigilância e Defesa do Estado (depois Polícia Internacional de Defesa do Estado e, ainda, Direcção-Geral de Segurança), Tribunal Militar Especial (depois Tribunais Plenários), prisões, locais de deportação e Colónia Penal do Tarrafal ("campo de concentração"), métodos de vigilância, tortura e assassínio, regras processuais arbitrárias e ilimitada capacidade de detenção de "suspeitos" (com ou sem julgamento); a perseguição ('moderada' ou sistemática) movida aos homens e mulheres "envolvidos" em formas de contestação pública - expressões culturais, declarações, abaixo-assinados, manifestações, greves, golpes militares ou quaisquer outras iniciativas/organizações oposicionistas (clandestinas ou semi-legais); a permanente recolha de informações e a discriminação, por motivos de ordem ideológica, no acesso, na progressão e na manutenção do emprego.

Protagonizada por Pedro Teotónio Pereira, Sebastião Garcia Ramires e outros, salienta-se a corporativização, - tutelada ou forçada, repressiva e enquadradora - das relações sociais e da economia: proibição das 
"associações de classe" livres e da greve, contratação colectiva e "previdência social" de âmbito sectorial, promulgação do Estatuto do Trabalho Nacional e actividade do Instituto Nacional do Trabalho e Previdência, condicionamento industrial e planos de fomento, organismos de coordenação económica e grémios patronais (do comércio, indústria, agricultura ou mistos), ordens e sindicatos nacionais, casas do povo e casas dos pescadores, Junta Central das Casas do Povo e Centros de Recreio Popular, Federação Nacional para a Alegria no Trabalho e Centros de Alegria no Trabalho. Pelo menos até à Segunda Guerra Mundial, a apropriação "mobilizadora" do 1 de Maio como "Festa do Trabalho Nacional".

Significativa é, igualmente, a existência do Secretariado de Propaganda Nacional (depois Secretariado Nacional de Informação, Cultura Popular e Turismo e, ainda, Secretaria de Estado da Informação e Turismo) e o impor de uma concepção oficial (nos primeiros anos semi-modernista e semi-conservadora) do que deveria ser a produção, o divulgar e o consumo da informação e de bens culturais (a "cultura do espírito" de António Ferro e outros); a presença contínua e exaustiva da censura, a colaboração por parte da grande maioria e a penalização dos órgãos de comunicação social, empresas e organizações da área da cultura que assumissem posturas dissonantes; a perseguição aos intelectuais oposicionistas e, frequentes vezes, o exílio; a propaganda ao regime como preocupação de todos os segmentos do aparelho de Estado e do universo corporativo, assim como de muitas entidades da "sociedade civil" - na "Metrópole" e nas "Colónias", junto das comunidades de emigrantes (com destaque para o Brasil), em outros países.

No âmbito do Ministério da Instrução Pública (Ministério Educação Nacional a partir de 1936), com Gustavo Cordeiro Ramos, António Faria Carneiro Pacheco e outros, procurou-se transformar o sistema de investigação, ensino e formação num agente eficaz de "reeducação e regeneração 
nacional" - de acordo com uma perspectiva elitista e tradicionalista primeiro, segundo critérios progressivamente meritocráticos e desenvolvimentistas a partir do pós-Segunda Guerra Mundial.

Os docentes e investigadores oposicionistas foram afastados, bloqueou-se o desenvolvimento das ciências sociais, investiu-se de forma cronicamente insuficiente; substituiram-se as Escolas Normais Superiores pelas Escolas do Magistério Primário, diminuiu-se a qualidade de formação dos professores do Ensino Primário, criou-se a figura dos "regentes escolares"; simplificaram-se e ideologizaram-se os currículos e os programas das disciplinas, adoptou-se a lógica do "livro único"; com algumas excepções derivadas da necessidade de preparar futuras "chefias", promoveram-se os métodos autoritários de relacionamento professor-aluno e a memorização; combateu-se a "co-educação" e confessionalizou-se, tanto o ensino não-superior público, como grande parte do subsistema privado, etc.

Criaram-se a Mocidade Portuguesa e a Mocidade Portuguesa Feminina depois da experiência efémera, porque instrumentada e datada, da Acção Escolar Vanguarda; sob a liderança, entre outros, dos Comissários Nacionais da MP Francisco José Nobre Guedes e Marcelo Caetano, estruturaram-se modalidades de controlo sobre todas as organizações não-oficiais de ou para jovens. Concretizou-se a instrumentalização da produção historiográfica e da Academia Portuguesa da História, da memória histórica, comemorações histórico-patrióticas, museologia e conservação do património; a tutela das associações desportivas e recreativas, capitalizando a colaboração assegurada pela generalidade das mesmas e facilitando a penalização das colectividades menos conformistas.

Sintomaticamente, a Subsecretaria de Estado das Corporações e Previdência Social, o SPN/SNI e o MEN contaram com a colaboração decisiva do Ministério das Obras Públicas e Comunicações, antes de 
mais durante o consulado paradigmático de Duarte Pacheco. Intervinha o MOPC em áreas como a atenuação dos efeitos mais explícitos da crise económica e social dos anos 30 através da canalização das verbas do Fundo de Desemprego para o financiamento de programas de obras públicas - utilizadores de mão-de-obra e vectores por excelência de propaganda da capacidade de realização, das potencialidades regeneradoras do Estado Novo; o urbanismo e a arquitectura, a montagem da Exposição do Mundo Português (1940), a acção da Direcção-Geral de Edifícios e Monumentos Nacionais, a construção de escolas e das "cidades universitárias" de Coimbra e de Lisboa, etc.

Assistiu-se a um empenhamento particular na fidelização do apoio de um universo feminino tendencialmente mais conservador, no manter do estatuto de inferioridade e subordinação da mulher (vertentes jurídico-moral, sócio-económica e religioso-cultural), no glorificar da "família tradicional"; à proibição do divórcio para casamentos católicos e à promoção do exemplo das "famílias numerosas". Instituiram-se a Obra das Mães pela Educação Nacional e a Acção Nacional Feminina; ocorreu uma intromissão estatal em aspectos da vida privada - sobretudo no que concerne ao casamento - de homens e mulheres que desempenhavam actividades profissionais específicas (professoras primárias, enfermeiras, telefonistas, diplomatas, oficiais das Forças Armadas). Manteve-se o lento crescimento dos mecanismos de apoio social (públicos, corporativos e privados) e, até ao fim dos anos cinquenta, a associação dos mesmos às noções de benemerência e de tutela sobre as "classes populares" sinónimo de "classes imprevidentes e perigosas", sobretudo nos meios urbanos e nos aglomerados mineiros.

Constata-se, finalmente, a identidade global de pontos de vista, divisão de esferas de influência e colaboração entre a ditadura e a Igreja/ "acção católica" - institucionalizada esta (delimitada, segmentada e hierarquizada) em 1934 sob a designação de Acção Católica Portuguesa; a 
discordância da Igreja com aspectos localizados de maior radicalismo fascizante ou de "excessivo intervencionismo estatal"; o aumento progressivo do número e da visibilidade/influência social dos católicos que afirmavam a sua oposição à ortodoxia político-religiosa estabelecida.

De acordo com Manuel Braga da Cruz e Maria Inácia Rezola ${ }^{21}$, regime teria mesmo concretizado uma postura "catolaica" em termos jurídico-constitucionais e político-institucionais, forçando a dissolução do Centro Católico Português e dos sindicatos católicos, impedindo que as organizações da "acção social católica" (Liga Operária Católica, Juventude Operária Católica, jornal $O$ Trabalhador, etc.) assumissem funções de natureza para-sindical, exigindo a subordinação do catolicismo nacional ao Estado "recristianizado" e a punição de sacerdotes ou leigos contestatários, bloqueando a criação da Universidade Católica Portuguesa.

Sobre a política externa do salazarismo, referem-se a aceitação da "Aliança Inglesa", tida como inevitável apesar do empenhamento no reforço da autonomia estratégica - por motivos de ordem ideológica e devido ao carácter não-paritário daquele instrumento de natureza político-diplomática; o desprezo pelos princípios fundadores da Sociedade das Nações e o reconhecimento da legitimidade dos irredentismos pós-1918, a participação na Guerra Civil de Espanha em apoio dos "nacionalistas" sublevados.

Quanto à gestão da neutralidade durante a Segunda Guerra Mundial, realce para a atitude perante a natureza do Terceiro Reich e do Eixo; para 'dossiers' como os dos refugiados, do Holocausto e dos contactos com a França de Vichy, do volfrâmio, do "ouro nazi" e do Acordo de Pagamentos entre o Banco de Portugal e o Banco de Inglaterra (Novembro de 1940), da cedência de bases nos Açores aos Aliados; para uma 
concepção global que se basearia numa paz negociada após o esmagamento da URSS, na preservação do poderio alemão (baluarte do anti-comunismo e garante do equilíbrio frente às potências demo-liberais), no fortalecimento de um bloco de países "com regimes de ordem" (Europa do sul e balcânica, América Latina) ${ }^{22}$.

Aventa-se, também, a relutância com que a ditadura portuguesa aceitou a intensificação do relacionamento bilateral com os EUA, a integração na Organização Europeia de Cooperação Económica/Plano Marshall, na Organização do Tratado do Atlântico Norte e na Organização das Nações Unidas. Tratar-se-ia da defesa da "supremacia europeia" e da correspondente "missão civilizadora" junto dos "povos inferiores" (africanos e asiáticos) perante a "agressividade neo-colonialista do capitalismo norte-americano" - "plutocrático" ou monopolista, "materialista e amoral" ou de consumo de massas; de uma exigência de pleno reconhecimento da Espanha franquista enquanto parceiro insubstituível na luta contra o "perigo comunista"; de prevenir as ameaças que adviriam para o regime de uma "excessiva abertura", quer a projectos de integração mundial ou europeia, quer a sociedades com sistemas políticos demoliberais ou democráticos e melhores condições de vida.

\footnotetext{
22 "Sei bem que é mais fácil criticar o passado que tomar deliberações para o futuro, mas dentro de poucos anos já não sofrerá discussão a tese de ter sido errada a política de guerra das potências anglo-saxónicas. E o maior número inclinar-se-á a ver que todos os erros derivaram de dois - a tese da rendição incondicional e a prioridade do teatro europeu de operações. Em parêntesis direi compreender perfeitamente que os países ocupados e devastados a ocidente defendessem outra concepção.

Daquelas posições proveio o esmagamento da Alemanha para além dos limites em que ainda poderia representar potência produtora, força defensiva e factor de equilíbrio no concerto europeu; e, pior que tudo isso, proveio também a inevitabilidade do avanço e ocupação russa até ao coração e posições dominantes da Europa [...]. Assim a Europa sofre miséria e tem medo. Medo de quê? Medo da Rússia; medo do comunismo. E parece ter razão." (Cfr. A.O. Salazar, 1945-1967, vol. IV, p. 288/289 - "Miséria e medo, características do momento actual", discurso proferido a 25 de Novembro de 1947)
} 
É, ainda, possível assinalar outras situações em que, ao longo da sua existência, o fascismo português - sob a liderança empenhada, não apenas arbitral, do próprio António de Oliveira Salazar - optou pela defesa dos valores ideológicos e dos equilíbrios político-sociais originários em contraponto a uma adaptação pragmática a novos contextos, à obtenção de mais elevados ritmos de crescimento económico ou, mesmo, de desenvolvimento. A partir do fim da década de cinquenta, o objectivo essencial passou a ser o garantir da sobrevivência, contrariando veleidades reformadoras ou tentativas "reviralhistas"23.

Integram-se neste âmbito o afastamento - temporário ou definitivo, negociado ou conflitual - de quadros destacados da ditadura que tivessem protagonizado iniciativas heterodoxas (Armindo Monteiro, Ferreira Dias Júnior, Daniel Barbosa, António Ferro, Marcelo Caetano, o General Craveiro Lopes, etc); a salvaguarda de interesses conservadores e tradicionalistas - agrícolas, comerciais e industriais; proteccionistas, corporativistas, colonialistas - e o apoio ao crescimento de um reduzido

${ }^{23}$ Elencam-se, a título de exemplo, a candidatura do General Humberto Delgado às eleições para a Presidência da República (25 de Outubro de 1957 a 7 de Junho de 1958) - tendo aquele oficial das Forças Armadas, ex-apoiante do Estado Novo, acabando por ser assassinado pela PIDE, em Espanha, no dia 13 de Fevereiro de 1965; a "carta aberta" de António Ferreira Gomes, Bispo do Porto, ao Presidente do Conselho sobre a situação social no nosso país (13 de Julho de 1958) e consequente exílio forçado daquele prelado (Abril de 1959 a Julho de 1970) - perante o silêncio dos outros membros da alta hierarquia da Igreja Católica portuguesa; o golpe militar situacionista-renovador de 11 a 13 de Abril de 1961, liderado pelo General Júlio Botelho de Moniz - Ministro da Defesa, ex-Chefe de Estado Maior General das Forças Armadas, oriundo dos sectores da direita radical; o golpe militar oposicionista de Beja (1 de Janeiro de 1962), com ligação a núcleos civis republicanos, "católicos progressistas" e, também, comunistas; a "crise académica" de Fevereiro a Junho de 1962, envolvendo sobretudo as Universidades de Lisboa e Coimbra; as comemorações do 1 de Maio de 1962, coordenadas pelo Partido Comunista Português, violentamente reprimidas pelas forças policiais, mas envolvendo dezenas de milhar de trabalhadores em greves (mineiros de Aljustrel, assalariados agrícolas do Alentejo e Ribatejo) e manifestações (Lisboa, Porto, Barreiro, Almada, etc). 
número de grandes grupos económicos monopolistas (relativamente modernizadores) à custa do bloquear de um desenvolvimento sustentável, social e regionalmente equilibrado, competitivo no plano internacional; a ausência de respostas para o acentuar do fluxo migratório e emigratório, reacção à pobreza endémica que marcava as zonas rurais ${ }^{24}$.

Nomeiam-se, igualmente, o provocar de um conflito com a União Indiana e de três guerras em Angola, Guiné-Bissau e Moçambique (1961-1974) devido à recusa em aceitar a independência das "províncias ultramarinas"; a adesão à Associação Europeia do Comércio Livre (1960) como forma de compatibilizar crescimento económico com a manutenção do regime, da lógica colonial, da especialização sócio-cultural e produtiva vigente - assente, apesar de algumas excepções sobretudo localizadas na "grande Lisboa" e no "grande Porto", em baixos salários e em rudimentares níveis de protecção social, na fraca qualificação escolar e

${ }^{24}$ "Sabe-se que a indústria tem rentabilidade superior à agricultura e que só pela industrialização se pode decisivamente elevar o nível de vida, como só por ela é possível atingir sem risco altas densidades demográficas. Sem suficiente industrialização nem teremos mercado local bastante para algumas produções agrícolas nem poderemos evitar completamente que os excessos de população se expatriem, como estão fazendo, nalguns casos em condições que não consideramos satisfatórias.

Temos por outro lado a agricultura, pela sua maior estabilidade, pelo seu enraizamento natural no solo e mais estreita ligação com a produção de alimentos, constitui a garantia por excelência da própria vida, e, devido à formação que imprime nas almas, manancial inesgotável de forças de resistência social. Aqueles que não se deixam obcecar pela miragem do enriquecimento indefinido, mas aspiram acima de tudo a uma vida que, embora modesta, seja suficiente, sã, presa à terra, não poderiam nunca, e muito menos nas precaríssimas condições da vida mundial, seguir por caminhos em que a agricultura cedesse à indústria e em que o solo e a gente não fossem estimulados a produzir o máximo possível [...].

Não estamos em face duma tese económica; encontramo-nos diante da necessidade de definir uma política que tem de atender ao conjunto de circunstâncias que se verificam no mundo. Sei que pagamos assim uma taxa de segurança; mas sei que a segurança e a modéstia têm também as suas compensações." (Cfr. A.O. Salazar, 1945-1967, vol. V, p. 103-105 - "O Plano de Fomento. Princípios e pressupostos", discurso proferido a 28 de Maio de 1953) 
profissional da mão-de-obra, nos limitados índices de produtividade, na ausência de liberdade sindical e política; a auto-anulação do essencial da "abertura marcelista" e a correspondente incapacidade para impedir o ampliar da contestação à ditadura, a estruturação do Movimento das Forças Armadas, o golpe militar de 25 de Abril de 1974 e o processo revolucionário que se lhe seguiu.

Comparando a evolução do fascismo espanhol com a do Estado Novo, verificam-se naquele, tanto elementos de maior violência repressiva, radicalismo político-ideológico, enquadramento e mobilização totalitários, identidade de perspectivas e modos de actuação com a Alemanha nacional-socialista e com a Itália fascista, como, inversamente, vectores de mais decidido empenhamento no assegurar de ajustamentos suficientes às novas relações de forças internacionais, em facilitar a normalização dos contactos com os outros Estados em geral e com as grandes potências demoliberais em particular, em garantir uma crescente integração na economia-mundo capitalista como etapa necessária ao alcançar do objectivo da modernização e do crescimento económicos.

Acerca da primeira vertente, realce para o número de mortos, presos, perseguidos, discriminados e exilados durante e até muito depois do fim da Guerra Civil; o culto da força e da juventude, do misticismo e da morte heróica, da violência e da guerra como valores positivos; a coesão no essencial manifestada pelas principais entidades antecessoras, fundadoras e estruturantes do regime durante as décadas de trinta a cinquenta - apesar de alguns conflitos e exclusões ${ }^{25}$; a explicitação legal

${ }^{25}$ Forças Armadas, polícias. Igreja e "acção católica", Carlistas, Juntas de Ofensiva Nacional-Sindicalistas de Ramiro Ledesma Ramos, Juntas Castellanas de Actuacion Hispanica de Onésimo Redondo, Falange Española de José António Primo de Rivera (executado), Confederación Española de Derechas Autónomas de Calvo Sotelo e José Maria Gil Robles (assassinado o primeiro, exilado em Portugal o segundo), Juventudes de Acción Popular, administração pública, sistemas judicial e educativo. 
e institucional dessa mesma "totalidade" através do acumular pelo General Francisco Franco da "personificação da Nação", da chefia do Estado, do Governo, das Forças Armadas e do Movimiento - a Falange Española Tradicionalista y de las Juntas de Ofensiva NacionalSindicalistas e um amplo conjunto de organizações dependentes (sindicais, de mulheres, de jovens, etc.); a confessionalização do Estado e da sociedade sob o lema da "Cruzada por Deus e pela Pátria", contra a "plutocracia demo-liberal e maçónica" e o "comunismo ateu".

Durante a Segunda Guerra Mundial - até ao fim de Agosto de 1942 -, salientaram-se a passagem do estatuto de neutralidade para o de não-beligerância, as facilidades concedidas à Alemanha e à Itália, a negociação dos termos da entrada no conflito como membro do Eixo, o envio da División Azul para colaborar na invasão da URSS e na "derrota do bolchevismo"; as ambições anexionistas relativamente a Portugal e a parcelas significativas do Norte de África, o mito da Hispanidad, os projectos de reordenamento autárcico da economia e de industrialização/ /militarização aceleradas com o apoio do Terceiro Reich, a defesa de uma "nova ordem" germânica com base no pressuposto de que a Espanha nela ocuparia uma posição cimeira.

Quanto aos indícios de pragmatismo e de capacidade de adaptação da ditadura - ou, a partir dos anos sessenta, de parcelas dominantes dos seus quadros intermédios e da base sócio-política de apoio -, lembram-se o regresso à situação de neutralidade e a adopção de uma postura defensiva - ou seja, também colaborante com os Aliados - após Setembro de 1942; a disponibilidade para ir negociando e reconhecendo a independência dos protectorados e colónias; apesar da manutenção de muitos bloqueios e atrasos, assimetrias regionais e injustiças sociais, a criação de condições para o retomar do processo de desenvolvimento enquanto semi-periferia do capitalismo; o estabelecimento dos consensos e acordos indispensáveis à derrota da "ala ultra-conservadora", a uma "transição 


\section{João Paulo Avelãs Nunes}

controlada" (não-revolucionária) do regime edificado pelos vencedores da Guerra Civil para uma sociedade demo-liberal, ou, mesmo, democrática.

\section{Conclusão}

Mesmo tendo em conta a complexidade da problemática em causa, arrisca-se a defesa da viabilidade e da maior pertinência, tanto no plano científico como no âmbito cívico, de um eventual "paradigma neo-moderno", ou seja, da vertente objectivante da rotura pós-moderna do resultado da desconstrução do paradigma moderno a partir de uma postura de "racionalismo (auto-)crítico".

Tal como se reconhecem as insuficiências e as sequelas negativas (em termos científico-tecnológicos, sociais e ambientais) da auto-suficiência isolacionista e dos cientismos inerentes aos princípios estruturantes do paradigma moderno, também se chama a atenção para as limitações cognitivas e para o carácter fortemente ideológico - de legitimação da hegemonia do capitalismo na actual fase de globalização, consumo de massas e neo-liberalismo - da corrente subjectivista (ou "irracionalista") e "neo-empirista" do paradigma pós-moderno.

O facto de se saudar a redescoberta, em novos moldes, dos objectos de estudo de reduzida extensão e maior espessura (ou profundidade) bem como dos inerentes "modelos micro", não significa, antes pelo contrário, que se recuse eficácia aos conceitos de média ou grande dimensão. Trata-se, em qualquer dos casos, de instrumentos complementares (ou não-alternativos) de análise, de "contra-realidades" abstractas cujo grau de operatividade deve ser regularmente avaliado.

A utilidade dos mesmos na abordagem de qualquer temática dependenderia, pois, entre outros factores, da riqueza do debate epistemológico-teórico existente, da capacidade demonstrada para auxiliar a compreen- 
são de regionalidades específicas e dos correspondentes vectores de integração no processo de consolidação, reprodução ou desagregação do social global. Dada a sua impossibilidade ontológica, a objectividade no sentido neutralidade ou imparcialidade, de ausência total de componentes ideológicos - e a identidade absoluta com a realidade não deveriam integrar os critérios de verificação da eficácia de cada modelo.

Em conjunto com as noções de autoritarismo e totalitarismo, uma versão genérica e globalizante do conceito de fascismo contribuiria, assim, para um conhecimento mais complexificante de ambas as experiências ibéricas ao longo do século XX, para uma comparação mais rigorosa com outras evoluções nacionais à escala europeia e mundial, para o rebater das leituras (talvez lineares e branqueadoras) dominantes na produção historiográfica e das outras ciências sociais.

\section{Documentação e bibliografia}

AFONSO, Rui, Injustiça. O caso Sousa Mendes, Lisboa, Editorial Caminho, 1990.

ALEXANDRE, Valentim, Velho Brasil, novas Áfricas. Portugal e o Império (1808-1975), Porto, Edições Afrontamento, 2000.

Annales. E.S.C., 43 ${ }^{\circ}$ Ano, ${ }^{\circ}$ 3, Maio-Junho de 1988, p. 561-704 ("Fascisme, nazisme").

BERSTEIN, Serge, Démocracies, régimes autoritaires et totalitarismes au $\mathrm{XX}$ siècle, Paris, Librairie Hachette, 1992.

BOURDIEU, Pierre, O poder simbólico (trad. do francês), Lisboa, Difel, 1989.

BLINKHORN, Martin (coord.), Fascists and conservatives, Londres, Unwin Hyman, 1990.

BRANCO, José Maria de Freitas, "O combate da racionalidade e a emergência de novas ideologias", Vértice, II Série, ${ }^{\circ}$ 72, Maio/Junho de 1996, p. 25 -30 .

CASTRO, Armando de, Conhecer o conhecimento, Lisboa, Editorial Caminho, 1989. 
CATALAN, Jordi, La economía española y la Segunda Guerra Mundial, Barcelona, Editorial Ariel, 1995.

CERQUEIRA, Silas, "L'Église Catholique et la dictature corporatiste portugaise", Revue Française de Science Politique, vol. XXIII, 1973, p. 473-513.

CLARENCE-SMITH, Gervase, $O$ Terceiro Império português (1815-1975) (trad. do inglês), Lisboa, Editorial Teorema, 1990.

COLloTTI, Enzo, Fascismo, fascismos (trad. do italiano), Lisboa, Editorial Caminho, 1992.

COMELlAS, Jose Luis, Historia de España contemporanea, Madrid, Ediciones Rialp, 1990, 2 edição.

CORNWELL, John, O Papa de Hitler. A história secreta de Pio XII (trad. do inglês), Lisboa, Terramar, 2000.

CRUZ, Manuel Braga da, "Notas para uma caracterização política do salazarismo", Análise Social, vol. XVIII, n ${ }^{\circ} 72-74,1982 a\left(3^{\circ}-5^{\circ}\right)$, p. $773-$ $-794$.

CRUZ, Manuel Braga da, As origens da democracia cristã em Portugal $e$ o salazarismo, Lisboa, GIS/Editorial Presença, $1982 b$.

CRUZ, Manuel Braga da, "A Revolução Nacional de 1926: da Ditadura Militar à formação do Estado Novo", Revista de História das Ideias, n 7, t. 2, 1985, p. 347-371.

CRUZ, Manuel Braga da, O partido e o Estado no salazarismo, Lisboa, Editorial Presença, 1988.

CRUZ, Manuel Braga da, O Estado Novo e a Igreja Católica, Lisboa, Editorial Bizâncio, 1998.

D'ASSAC, Jacques Ploncard, Doutrinas do nacionalismo, Lisboa, SNI, 1962. DROZ, Bernard e ROWLEY, Anthony, História do Século XX (trad. do francês), 4 volumes, Lisboa, Publicações Dom Quixote, 1988-1993.

ERLER, Gernot e outros, L'histoire escamotée. Les tentatives de liquidation du passé nazi en Allemagne (trad. do alemão), Paris, Éditions La Découverte, 1988.

ESPADAS BURGOS, Manuel, Franquismo y politica exterior, Madrid, Ediciones Rialp, 1988.

O Estado Novo. Das origens ao fim da autarcia (1926-1959), 2 volumes, Lisboa, Editorial Fragmentos, 1987. 
FARINHA, Luís, $O$ reviralho. Revoltas republicanas contra a Ditadura $e$ o Estado Novo (1926-1940), Lisboa, Editorial Estampa, 1998.

Ofascismo em Portugal. Actas do Colóquio, Lisboa, A Regra do Jogo, 1982.

FERNÁNDEZ CLEMENTE, Eloy, "La historia económica de España en los últimos veinte años (1975-1995). Crónica de una escisión anunciada", Revista de Historia Jerónimo Zurita, $\mathrm{n}^{\circ}$ 71, 1995, p. 47-58.

FERREIRA, José Medeiros, $O$ comportamento político dos militares. Forças Armadas e regimes políticos em Portugal no Século $X X$, Lisboa, Editorial Estampa, 1996, $2^{a}$ edição.

FERRO, António, Salazar. O homem e a sua obra, Lisboa, Empresa Nacional de Publicidade, 1933.

FORCADELL ÁLVAREZ, Carlos, "La historiografía contemporánea española actual: sínteses y microanálisis", Revista de Historia Jerónimo Zurita, n 71, 1995, p. 47-58.

FURET, François e NOLTE, Ernst, Fascisme et communisme, Paris, Librairie Plon, 1998.

GALLAGHER, Tom, Portugal: a twentieth-century interpretation, Manchester, MUP, 1983.

GARCÍA PÉREZ, Rafael, Franquismo y Tercer Reich, Madrid, Centro de Estudios Constitucionales, 1994.

GASPAR, Carlos, "Estruturas, alianças e regimes. As relações entre Portugal e Espanha (1926-1974)", I Encontro Internacional "Relações Portugal-Espanha: cooperação e identidade. Actas, Porto, CEPESE/FRAH, 2000, p. 165-209.

GEORGEL, Jacques, Franco e o franquismo (trad. do francês), Lisboa, Publicações Dom Quixote, 1974.

GEORGEL, Jacques, $O$ salazarismo (trad. do francês), Lisboa, Publicações Dom Quixote, 1985.

GEORGEL, Jacques, Les eurodictatures. Etude comparative, Paris, Éditions Apogée, 1999.

GRIFFIN, Roger, The nature of fascism, Londres, Routledge, 1996, $3^{\star}$ edição. Historia de España, Madrid, Historia 16, 1986.

HOBSBAWM, Eric, A era dos extremos. História breve do século XX (1914-1991) (trad. do inglês), Lisboa, Editorial Presença, 1996. 
João Paulo Avelãs Nunes

HUSSON, Edouard, Une culpabilité ordinaire? Hitler, les allemands et la Shoah. Les enjeux de la controverse Goldhagen, Paris, François-Xavier de Guibert, 1997.

Informe para la Comisión de investigación de las transacciones de oro procedente del Tercer Reich durante la Segunda Guerra Mundial, Madrid, 1998 (policopiado).

JANEIRO, Helena Pinto, Salazar e Pétain. Relações luso-francesas durante a II Guerra Mundial (1940-44), Lisboa, Edições Cosmos, 1998.

JIMENEZ REDONDO, Juan Carlos, Franco e Salazar. As relações luso-espanholas durante a Guerra Fria (trad. do castelhano), Lisboa, Assírio \& Alvim, 1996.

KANTIN, Georges, MANCERON, Gilles (coord.), Les échos de la mémoire. Tabous et enseignements de la Seconde Guerre Mondiale, Paris, Le Monde Éditions, 1991.

LEAL, Ernesto Castro, Nação e nacionalismos. A Cruzada Nacional D. Nuno Álvares Pereira e as origens do Estado Novo (1918-1938), Lisboa, Edições Cosmos, 1999.

LEE, Stephen J., The european dictatorships (1918-1945), Londres, Routledge, 1996, 9" edição.

LÉONARD, Yves, Salazarismo e fascismo (trad. do francês), Mem Martins, Editorial Inquérito, 1998.

Le livre noire du communisme, Paris, Éditions Robert Laffont, 1997.

LOFF, Manuel, Salazarismo efascismo na época de Hitler (1936-1942), Porto, Campo das Letras, 1997.

LOFF, Manuel, "Los regímenes autoritarios", Ayer, n. ${ }^{\circ}$ 37, 2000, p. 125-162.

LOUÇÃ, António, Hitler e Salazar: comércio em tempos de guerra (1940-1944), Lisboa, Terramar, 2000.

LUCENA, Manuel de, A evolução do sistema corporativo português, 2 volumes, Lisboa, Perspectivas \& Realidades, 1976.

LUCENA, Manuel de, "Interpretações sobre o salazarismo: notas de leitura crítica", Análise Social, vol. XX, n 83, 1984 (4), p. 423-451.

LUCENA, Manuel de, "Notas para uma teoria dos regimes fascistas", Análise Social, vol. XXVIII, ${ }^{\circ} 125 / 126,1994\left(1^{\circ} / 2^{\circ}\right)$, p. 9-32.

MACCIOCCHI, Maria-Antonieta (dir.), Eléments pour une analyse dufascisme, 2 volumes, Paris, Union Générale d'Édition, 1976. 
MADEIRA, João, Os engenheiros de almas. $O$ Partido Comunista $e$ os intelectuais (dos anos trinta a inícios de sessenta), Lisboa, Editorial Estampa, 1996.

MARCADÉ, Jacques, Le Portugal au XX Siècle (1910-1985), Paris, PUF, 1988. MARTÍNEZ-RISCO DAVIÑA, Luis, $O$ ensino da história no bacharelato franquista (periodo 1936-1951), Corunha, Ediciós do Castro, 1994.

MEDEIROS, Fernando, A sociedade e a economia portuguesas nas origens do salazarismo, Lisboa, A Regra do Jogo, 1978.

MEDINA, João, Salazar, Hitler e Franco. Estudos sobre Salazar e a ditadura, Lisboa, Livros Horizonte, 2000.

MENESES, Filipe Ribeiro de, União Sagrada e sidonismo. Portugal em guerra (1916-1918), Lisboa, Edições Cosmos, 2000.

MILZA, Pierre e BERSTEIN, Serge, Dictionnaire historique des fascismes et du nazisme, Bruxelas, Éditions Complexe, 1992.

MÓNICA, Maria Filomena, Educação e sociedade no Portugal de Salazar, Lisboa, GIS/Editorial Presença, 1978.

MORAIS, João e VIOLANTE, Luís, Contribuição para uma cronologia dos factos económicos e sociais: Portugal, 1926-1985, Lisboa, Livros Horizonte, 1986.

MORODO, Raúl, "Ensayo sobre el totalitarismo", Revista da Faculdade de Letras, $5^{a}$ Série, $n^{\circ}$ 19/20, 1995/1996, p. 199-210.

NOLTE, Ernst, Les mouvements fascists. L'Europe de 1919 à 1945 (trad. do alemão), Paris, Calman-Levy, 1969.

NORA, Pierre (dir.), Ensaios de ego-história (trad. do francês), Lisboa, Edições $70,1989$.

NUNES, Adérito Sedas, "Questões preliminares sobre as ciências sociais", Análsie Social, vol. VIII, $\mathrm{n}^{\circ}$ 30/31, 1970, p. 201-298.

NUNES, António José Avelãs, Noção e objecto da economia política, Coimbra, FDUC, 1995.

NUNES, João Arsénio e GOMES, Ana Calapez, "Uma luta em tomo da imagem histórica: a "polémica dos historiadores" na Alemanha", Vértice, II Série, n 22, Janeiro de 1990, p. 99-104.

NUNES, João Paulo Avelãs e outros, O CADC de Coimbra, a democracia cristã e os inícios do Estado Novo (1905-1934), Coimbra, FLUC, 1993a. 
NUNES, João Paulo Avelãs, "O conceito de "fascismo" na história recente de Portugal", Vértice, II Série, $n^{\circ}$ 52, Janeiro/Fevereiro de 1993b, p. 53-65.

NUNES, João Paulo Avelãs, "História e ideologia no Estado Novo", Vértice, II Série, $n^{\circ}$ 56, Setembro/Outubro de 1993b, p. 13-23.

NUNES, João Paulo Avelãs, A história económica e social na Faculdade de Letras da Universidade de Coimbra (1911-1974), Lisboa, IIE, 1995a.

NUNES, João Paulo Avelãs, "As organizações de juventude do Estado Novo (1934-1949)", Revista de História das Ideias, vol. 17, 1995b, p. 167-227.

NUNES, João Paulo Avelãs, "Ensino da História e exercício da cidadania. 0 exemplo da Revolução de 25 de Abril de 1974", O Ensino da História, III Série, $n^{\circ}$ 15, Outubro de 1999a, p. 13-19.

NUNES, João Paulo Avelãs, "Portugal, Espanha, o volfrâmio e os beligerantes durante e após a Segunda Guerra Mundial", Revista Portuguesa de História, t. XXXIII, 1999b, vol. II, p. 789-823.

Ó, Jorge Ramos do, Os anos de Ferro. O dispositivo cultural durante a "Política do Espírito" (1933-1939), Lisboa, Editorial Estampa, 1999.

OLIVEIRA, César, Portugal e a II República de Espanha (1931-1936), Lisboa, Perspectivas \& Realidades, 1985.

OLIVEIRA, César, Salazar e a Guerra Civil de Espanha, Lisboa, Edições $O$ Jornal, 1987.

OLIVEIRA, César, Salazar e o seu tempo, Lisboa, Edições O Jornal, 1991.

ORGANSKY, A.F.K., The stages of politicai development, Nova Iorque, Alfred A. Knopf, 1965.

PASAMAR ALZURIA, Gonzalo, Historiografia e ideología en la post-guerra española. La ruptura de la tradición liberal, Saragoça, Prensas Universitarias de Zaragoza, 1991.

PATRIARCA, Maria de Fátima, A questão social no salazarismo, 2 volumes, Lisboa, IN/CM, 1995.

PAUlo, Heloisa de Jesus, Estado Novo e propaganda em Portugal e no Brasil, Coimbra, Livraria Minerva, 1994.

PAYNE, Stanley G., Fascism. Comparison and definition, Madison, University of Wisconsin Press, 1980.

PAYNE, Stanley G., "'Fascism" or "bureaucratic authoritarianism"?", Estudos de homenagem a A.H. de Oliveira Marques, Lisboa, Editorial Estampa, 1983, vol. II, p. 523-531. 
PAYNE, Stanley G., La Espana contemporânea, Madrid, Editorial Playor, 1987.

PEREIRA, José Pacheco, Álvaro Cunhal. Uma biografia política, Lisboa, Temas e Debates, vols. 1 e 2, 1999-2001.

PIMENTEL, Irene Flunser, História das organizaçõos femininas no Estado Novo, Lisboa, Círculo de Leitores, 2000.

PINTO, António Costa, "O salazarismo na recente investigação sobre o fascismo europeu - velhos problemas novas respostas?", Análise Social, vol. XXV, $n^{\circ} 108 / 109,1990\left(4^{\circ} / 5^{\circ}\right)$, p. 695-713.

PINTO, António Costa, O salazarismo e o fascismo europeu, Lisboa, Edtorial Estampa, 1992.

PINTO, António Costa, Os camisas azuis, Ideologia, elites e movimentos fascistas em Portugal (1914-1945), Lisboa, Editorial Estampa, 1994.

PINTO, António Costa e COVA, Anne, "O salazarismo e as mulheres. Uma abordagem comparativa", Penélope, $\mathrm{n}^{\circ}$ 17, 1997, p. 71-94.

PINTO, António Costa (org.), Modern Portugal, Palo Alto, The Society for the Promotion of Science and Scholarship, 1998.

PINTO, António Costa, "O império do professor: Salazar e a elite ministerial do Estado Novo (1933-1945)", Análise Social, vol. $X X X V$, n. ${ }^{\circ}$ 157, Inverno de 2001, p. 1055-1076.

PITA, Gabriel de Jesus, "A Igreja Católica perante os nacionalismos europeus entre as duas guerras mundiais: o caso específico português", Revista da Faculdade de Letras [UL], 5' Série, ${ }^{\circ}$ 21/22, 1996/1997, p. 231-242.

PRETO, Rolão, Salazar e a sua época, Lisboa, Imprensa Moderna, 1933.

PRESTON, Paul, The politics of revenge. Fascism and the military in 20thcentury Spain, Londres, Routledge, 1995, $2^{n}$ edição.

RABY, Dawn Linda, Resistência antifascista em Portugal (1941-1974) (trad. do inglês), Lisboa, Edições Salamandra, 1990.

REIS, António (dir.), Portugal Contemporâneo, Lisboa, Publicações Alfa, 1991, vol. IV ("Ascensão e consolidação do Estado Novo (1926-1958)").

Revista de História das Ideias, ${ }^{\circ} 16$ e 17, 1994 e 1995 ("Do Estado Novo ao 25 de Abril").

A Revolução continua: União Nacional, Mocidade, Legião, Lisboa, Edições SPN, 1943. 
REZOLA, Maria Inácia, $O$ sindicalismo católico no Estado Novo (1931-1948), Lisboa, Editorial Estampa, 1999.

RIBEIRO, Maria da Conceição, A polícia política no Estado Novo (1926-1945), Lisboa, Editorial Estampa, 1995.

RODRIGUES, António Augusto Simões, História comparada: Portugal, Europa e o Mundo. Uma visão cronológica, Lisboa, Temas e Debates, vol. 2, 1997. RODRIGUES, Nuno Luís, A Legião Portuguesa. A milícia do Estado Novo (1936-1944), Lisboa, Editorial Estampa, 1996.

ROLLO, Fernanda, Portugal e o Plano Marshall (1947-1952), Lisboa, Editorial Estampa, 1994.

ROSAS, Fernando, "A crise do liberalismo e as origens do "Autoritarismo Moderno" e do Estado Novo em Portugal", Penélope, n ${ }^{\circ}$,1989, p. 97-114. ROSAS, Fernando, Portugal entre a paz e a guerra (1939-1945), Lisboa, Editorial Estampa, 1990.

ROSAS, Fernando (coord.), Portugal e o Estado Novo (1930-1960), SERRÃO, Joel e MARQUES, A.H. de Oliveira (dir.), Nova história de Portugal, Lisboa, Editorial Presença, vol. XII, 1992.

ROSAS, Fernando (coord.), O Estado Novo (1926-1974), MATTOSO, José (dir.), História de Portugal, Lisboa, Círculo de Leitores, 1994, vol. 7.

ROSAS, Fernando e BRITO, José Maria Brandão de (dir.), Dicionário de história do Estado Novo, 2 volumes, Lisboa, Círculo de Leitores, 1996.

ROSAS, Fernando, "Estado Novo, Universidade e depuração política", Seara Nova, ${ }^{\circ}$ 62, Outubro-Dezembro de 1998, p. 11-20.

ROSAS, Fernando, Salazarismo e fomento económico, Lisboa, Editorial Notícias, 2000.

ROSAS, Fernando, "O salazarismo e o homem novo: ensaio sobre o Estado Novo e a questão do totalitarismo", Análise Social, vol. XXXV, n. ${ }^{\circ}$ 157, Inverno de 2001, p. 1031-1054.

ROUSSO, Henry (dir.), Stalinisme et nazisme. Histoire et mémoire comparées, Bruxelas, Éditions Complexe, 1999.

Salazar e o salazarismo, Lisboa, Publicações Dom Quixote, 1989.

SALAZAR, António de Oliveira, Discursos $e$ notas políticas, 6 volumes, Coimbra, Coimbra Editora, 1945-1967.

SÁNCHEZ CERVELLÓ, Josep, A Revolução portuguesa e a sua influência na transição espanhola (1961-1976) (trad. do castelhano), Lisboa, Assírio \& Alvim, 1993. 
SANTOS, Boaventura Sousa, Um discurso sobre as ciências, Porto, Edições Afrontamento, 1987.

SCHIRÒ, Luís Bensaja dei, "Fascismo mussoliniano e fascismo salazarista", Estudos Italianos em Portugal, $\mathrm{n}^{\circ}$ 51-53, 1988-1990, p. 263-294.

STERNHELL, Zeev, Nascimento da ideologia fascista (trad. do francês), Venda Nova, Bertrand Editora, 1995.

TAMAMES, Ramon (dir.), A Guerra Civil de Espanha 50 anos depois (trad. do castelhano), Lisboa, Edições Salamandra, 1986.

TEIXEIRA, Nuno Severiano e PINTO, António Costa (coord.), A Primeira República entre o liberalismo e o autoritarismo, Lisboa, Edições Colibri, 2000.

TELO, António José, O sidonismo e o movimento operário. Luta de classes em Portugal (1917-1919), Lisboa, Ulmeiro, 1977.

TELO, António José, Decadência e queda da $1^{a}$ República portuguesa, 2 volumes, Lisboa, A Regra do Jogo, 1980-1984.

TELO, António José, Portugal e a NATO. O reencontro da tradição atlântica, Lisboa, Edições Cosmos, 1996.

TELO, António José, A neutralidade portuguesa e o ouro nazi, Lisboa, Quetzal Editores/MNE, 2000.

THOMAS, Hugh, A Guerra Civil de Espanha (trad. do inglês), Lisboa, Editora Ulisseia, s.d.

TORGAL, Luís Reis, "Salazarismo, fascismo, Europa", Vértice, II Série, $\mathbf{n}^{\circ} 52$, Janeiro/Fevereiro de 1993, p. 41 -52.

TORRE GÓMEZ, Hipólito de la, Do "perigo espanhol" à amizade peninsular (1919-1930) (trad. do castelhano), Lisboa, Editorial Estampa, 1998.

TORRE GóMEZ, Hipólito de la e TELO, António José, Portugal e Espanha nos sistemas internacionais contemporâneos, Lisboa, Edições Cosmos, 2000.

UMBRAL, Francisco, Madrid 1940. Memórias de um jovem fascista (trad. do castelhano), Porto, Campo das Letras, 1994.

VALENTE, José Carlos, Estado Novo e alegria no trabalho. Uma história política da FNAT (1935-1958), Lisboa, INATEL/Edições Colibri, 1999.

VALÉRIO, Nuno, "Oliveira Salazar (1889-1970) et le régime autoritaire portugais (1926-1974)", Estudos de Economia, vol. XIII, ${ }^{\circ}$ 2, Janeiro-Março de 1993, p. 129-144. 
348__ João Paulo Avelãs Nunes

VÁZQUEZ MONTALBÁN, Manuel, Autobiografia del General Franco, Barcelona, Editorial Planeta, 1992.

Vértice, II Série, $\mathrm{n}^{\circ}$ 13, Abril de 1989, p. 9-90 ("Salazar e o salazarismo").

WALLERSTEIN, Immanuel, The modern world-system, 3 volumes, Nova Iorque, Academic Press, 1974-1989.

WOOD, Ellen Meiksins, Democracy against capitalism. Renewing historical materialism, Cambridge, CUP, 1996, 2" edição.

WOOLF, S.J. (coord.), O fascismo na Europa (trad. do inglês), Lisboa, Editora Meridano, 1978. 